\title{
A PRELIMINARY STUDY OF THE PREVALENCE OF INTESTINAL PARASITES IN IMMUNOCOMPROMISED PATIENTS WITH AND WITHOUT GASTROINTESTINAL MANIFESTATIONS
}

\author{
Jorge Humberto BOTERO(1), Amanda CASTAÑO(1,2), Marta Nelly MONTOYA(1), Norma Elena OCAMPO(1), Marta Inés HURTADO(1,2) \& Mónica María LOPERA(1)
}

\begin{abstract}
SUMMARY
The objective of the present study was to determine the prevalence of the intestinal parasites most commonly found in immunocompromised patients. A group of 111 individuals with acute lymphoid leukaemia (ALL), chronic myeloid leukaemia (CML), human immunodeficiency virus (HIV) and other immunocompromised conditions (principally haematological disorders) was selected. A battery of tests was performed on each individual to identify the presence of parasites (three stool specimens with saline solution and Lugol both directly and by concentration, culture and special staining). No significant differences were found among the frequencies of the different parasites with the several types of immunocompromised conditions. The overall frequencies of potentially pathogenic and opportunistic parasites were 32.4\% (36/111) and 9\% (10/111) respectively, the most frequently encountered among the latter being Cryptosporidium sp., Microsporidia spp. and Strongyloides stercoralis.
\end{abstract}

KEYWORDS: Immunocompromised patients; Opportunistic parasites; Enteroparasites; Primary immunodeficiency.

\section{INTRODUCTION}

Although enteroparasitic infections constitute a serious public health problem in developing countries with inadequate sanitary conditions, they are not exclusive to them. Many types of helminths and protozoal intestinal parasites affect man, provoking a wide range of symptoms that are generally associated with the gastrointestinal tract and dependent on demographic, socio-economic, physiological and immunological factors.

Patients with some type of immunocompromised condition and those submitted to immunosuppressive therapy have an increased probability of acquiring parasitic infections, generally with a high degree of severity $9,17,23,24,25$.

The immune response of an immunocompetent host against parasites is a complex system in which both cellular and humoral defence mechanisms intervene ${ }^{2}$. These mechanisms involve the production of pro-inflammatory cytokines and the presentation of antigens to the $\mathrm{T}$ cells by means of antigen-presenting cells that express class II (MHCII) molecules ${ }^{22,27}$. The intestinal mucosae organised in the Peyer's patches and immunoglobulin-secretory plasma cells present important natural barriers $^{8}$. Activated B cells also produce and secrete $\operatorname{IgA}$ that impedes the adhesion of extracellular parasites ${ }^{20}$. Intracellular parasites are controlled by T helper type I lymphocytes (LT1) ${ }^{2,20}$.

Patients who present immunocompromised cellular or humoral responses have qualitative and/or quantitative alterations that impede them from acting efficiently against the infections, manifested in deterioration of their general condition.

Parasitic infections that cause auto-limited diarrhoea in immunocompetent patients may cause profuse diarrhoea in immunocompromised individuals, generally accompanied by loss of weight, anorexia, malabsorption syndrome and in some cases fever and abdominal pain. In such patients, parasites such as Cryptosporidium parvum, Enterocytozoon bieneusi, Encephalytozoon intestinalis and Strongyloides stercoralis may disseminate to other organs such as the bronchia, bile and liver ducts, producing symptomatology specific to the organ affected ${ }^{5,10,11,12,13,15,25,28}$.

The parasite Giardia duodenalis affects both immunocompetent individuals and immunocompromised patients, particularly those with common variable or congenital hypogammaglobulinaemia and those in advanced states of AIDS with prolonged diarrhoea ${ }^{1,14,16}$.

Both Cyclospora cayetanensis and Isospora belli have been incriminated as causes of prolonged diarrhoea, especially in AIDS patients, although they are thought to cause auto-limited diarrhoea in immunocompetent individuals ${ }^{15,18,25}$.

The intestinal non-opportunistic pathogenic parasites most frequently encountered in immunocompromised hosts include Entamoeba histolytica/dispar, Balantidium coli and others, but these produce

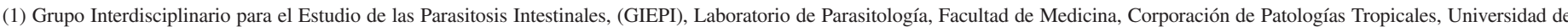
Antioquia. Colombia

(2) Escuela de Bacteriología y Laboratorio Clínico, Universidad de Antioquia

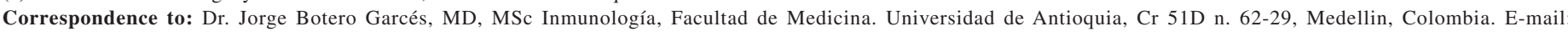
jbotero@quimbaya.udea.edu.co 


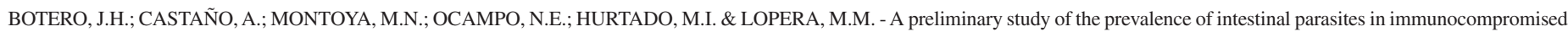
patients with and without gastrointestinal manifestations. Rev. Inst. Med. trop. S. Paulo, 45(4): 197-200, 2003.

symptomatology similar to that observed in immunocompetent individuals.

The behaviour of these parasitosis in immunocompromised patients is currently unknown. A preliminary study was therefore carried out to determine the prevalence of the enteroparasites most frequently encountered in these individuals.

\section{MATERIALS AND METHODS}

A descriptive prospective cohort study design was used. All samples analysed in this study were remitted to the Intestinal Parasite Laboratory at Medical School, Universidad de Antioquia, over a period of 12 months, a total 111 patients aged 0-70 years old, with confirmed diagnosis of immunodeficiency or treated with immunosuppressive therapy according to the diagnostic criteria of the 1994 International Congress of the WHO, were identified for inclusion in the study. The sample in this study was not randomised.

All the individuals received information about the study and signed consent forms authorising their participation or that of their children. The ethics committee of the University of Antioquia approved the methodology, considering there to be no risks against the physical wellbeing, integrity or right to anonymity of the participants.

A preliminary precoded clinico-epidemiological survey was performed on all these patients, and three fresh stool specimens were analysed from each person, both directly and by concentration with saline solution and Ritchie's technique. Harada Mori cultures were made for Strongyloides stercoralis and samples were stained by a modified ZiehlNielsen technique for Cryptosporidium parvum, Isospora belli and Cyclospora cayetanensis ${ }^{3}$. Finally, gram chromotrope staining was used for the diagnosis of microsporidia ${ }^{18,19}$.

In this study, the intestinal parasites considered to be potentially pathogenic were Entamoeba histolytica/dispar, Giardia lamblia, Trichuris trichiuria, Ascaris lumbricoides and hookworms; the opportunistic intestinal parasites were Cryptosporidium parvum, Cyclospora cayetanensis, Isospora belli, microsporidia and Strongyloides stercoralis; and the non-pathogenic parasites were Entamoeba coli, Endolimax nana and Iodamoeba butschlii ${ }^{4}$.

The variables analysed included age, sex, occupation, gastrointestinal symptoms or manifestations, type of parasitosis, multiparasitism and immunocompromised condition.

\section{STATISTICAL ANALYSIS}

Statistical software for Windows was used to determine the relation between the type of parasitism and immunodeficiency, age, sex and occupation. The degree of association was determined by means of the $\mathrm{Chi}^{2}$ test.

\section{RESULTS}

All 111 patients were confirmed as being immunocompromised according to the criteria described in Materials and Methods (Table 1). Of 111 patients $59(53.1 \%)$ were aged $0-14 ; 16(14.2 \%)$ aged $15-29 ; 28$
(25.2\%) aged 30-49 and $8(7.2 \%)$ aged 50 or over. Males constituted 69 $(62.2 \%)$ of the study population and females 42 (37.8\%). Only one case of multiparasitism occurred (Table 2). The more common immunodeficiencies (IDFs) were Acute Lymphoid Leukemia (ALL), Chronic Myeloid Leukemia (CML) and Human Immunodeficiency Virus (HIV). However, several other IDFs were encountered, i.e., Hypogammaglobulinemia, Common Variable Immunodeficiency, and several cancers and hematological disorders other than ALL and CML.

Of the 111 immunocompromised patients, 53 (47.7\%) did not present any clinical manifestation associated with the gastrointestinal tract, while $58(52.3 \%)$, presented abdominal pain, diarrhoea or flatulence (Table 1).

Table 1

Distribution of the different types of immunocompromised clinical manifestations related to the gastrointestinal tract, including potentially pathogenic and opportunistic parasites

\begin{tabular}{lccrrrr}
\hline \multirow{2}{*}{ Agent } & \multicolumn{2}{c}{ Positive } & \multicolumn{2}{c}{ Negative } & \multicolumn{2}{c}{ Total } \\
& + GIT & -GIT & + GIT & -GIT & \multicolumn{1}{c}{$\mathrm{N}^{\mathbf{0}} \%$} \\
\hline ALL & 4 & 3 & 10 & 16 & 33 & 29.73 \\
CML & 1 & 0 & 3 & 4 & 8 & 7.21 \\
HIV & 17 & 2 & 14 & 3 & 36 & 32.43 \\
Other IDF's & 7 & 1 & 2 & 24 & 34 & 30.63 \\
\hline Total & $\mathbf{2 9}$ & $\mathbf{6}$ & $\mathbf{2 9}$ & $\mathbf{4 7}$ & $\mathbf{1 1 1}$ & $\mathbf{1 0 0 . 0}$ \\
\hline
\end{tabular}

$\mathbf{A L L}=$ Acute Lymphoid Leukemia; $\mathbf{C M L}=$ Chronic Myeloid Leukemia; IDF = Immunodeficiencies $; \mathrm{N}=$ absolute number $;$-GIT $=$ without clinical manifestations associated to GIT; +GIT = with symptomatology related to GIT (mainly diarrhoea and/or abdominal pain). In Table 1, patients in whom no pathogenic parasites were found and those who did not reveal any type of parasite in faecal material analyses were both considered to be negative.

It is important to point out that only $5 / 53(11.3 \%)$ of patients without associated gastrointestinal manifestations were positive for intestinal parasites recognised as human pathogens, based on faecal samples. Symptomatic patients presented a frequency of 29/58 (50.0\%).

The faecal contamination index (FCI), calculated using the equation $\mathrm{FCI}=(\mathrm{PP}+\mathrm{PNP}+\mathrm{both}) / \mathrm{N} \times 100 \%$, was $39.0 \%$. This value is very close to that of the Colombian population in general, i.e., 30-38\% (Table 2). It should be pointed out that opportunistic parasites were not taken into account in this calculation, since no reference values are available for the Colombian population.

Table 2

Absolute frequency of the results of coprological analyses in immunocompromised patients

\begin{tabular}{lc}
\hline Faecal results & N \\
\hline Negative & 61 \\
Pathogenic Parasites (PP) & 20 \\
Non-Pathogenic Parasites (NPP) & 15 \\
Both types of Parasites (BP) & 6 \\
Opportunistic parasites & 10 \\
\hline Total & $\mathbf{1 1 2}$ \\
\hline
\end{tabular}

One of the patients was infected with opportunistic parasites as well as a nonpathogenic organism, so that the total number of coprological records is 112 among the 111 individuals evaluated. 
The frequencies of the parasites most commonly found in immunocompromised hosts are shown in Table 3. The potentially pathogenic parasites most frequently encountered were Entamoeba histolytica/dispar (10.0\%) and Giardia lamblia (7.2\%).

Table 3

Distribution of potentially pathogenic and opportunistic intestinal parasites

\begin{tabular}{lll}
\hline Parasite & Number & $\%$ \\
\hline Entamoeba histolytica/dispar & 11 & 9.91 \\
Giardia lamblia & 8 & 7.21 \\
Strongyloides stercoralis & 4 & 3.60 \\
Trichuris trichiuria & 4 & 3.60 \\
Ascaris lumbricoides & 1 & 0.90 \\
Hookworm & 2 & 1.80 \\
Cryptosporidium parvum & 4 & 3.60 \\
Microsporidia sp. & 2 & 1.80 \\
\hline Total & $\mathbf{3 6 / 1 1 1}$ & $\mathbf{3 2 . 4 3}$ \\
\hline
\end{tabular}

Although no statistically significant differences were seen between the different types of immunocompromised condition evaluated with respect to the presence of intestinal parasites at $p \geq 0.05$, a strong correlation was observed between the presence of parasites and symptomatology $(\mathrm{p}<0.05)$.

In the study population $32.4 \%$ of the patients were positive for potentially pathogenic parasites. The numbers and percentages of patients harbouring each species are shown in Table 3.

\section{DISCUSSION}

The overall prevalence of the intestinal parasites in the study population was lower than that reported by different researchers on the Colombian population, according to the results of the 1980 National Morbidity Survey ${ }^{7}$. The percentage distribution of each of the parasite species was also lower (Table 3).

It is important to point out that the patients with clinical manifestations related to gastro-intestinal tract among the different groups of immunocompromised individuals present a higher number of potentially pathogenic parasites than the asymptomatic patients (Table 1). However, a large proportion of symptomatic patients (29/58) was negative for potentially pathogenic parasites, which confirms the need to look for other causes associated with clinical gastrointestinal manifestations. On the other hand, it should be emphasised that the selection criteria in this study were such that some of the patients included had cancers, IDFs and haematological alterations known to produce gastro-intestinal manifestations, which could also have been due to the treatments used. It was thus not possible to discriminate in all cases whether symptomatologies were due to intestinal parasites or the conditions mentioned.

Among the immunocompromised patients, the presence of potentially pathogenic parasites was expected to be associated with gastrointestinal manifestations. However it was found that six of the 53 asymptomatic patients presented parasitoses that were potentially pathogenic. Three were positive for Entamoeba histolytica/dispar, suggesting that the parasite encountered was the non-pathogenic E. dispar, although no attempt was made to differentiate species in this study.

The nematode Strongyloides stercoralis was present in two asymptomatic HIV-positive patients. This observation agrees with some published reports of studies where no relation was seen between $S$. stercoralis and prolonged diarrhoea in HIV-positive individuals. Complications involving this parasite have been associated with immunosuppressive therapy, especially the use of corticosteroids ${ }^{12,21,24}$. It is postulated that the female $S$. stercoralis possesses receptors for these drugs that induce its multiplication and development, contributing to its dissemination to other organs and resulting in severe complications. The above is especially interesting since it would affect the host-parasite interaction through mechanisms of pathogenicity and avoidance of the immune response, as well as the type of immunocompromised condition displayed by the patient and his/her response to the parasite ${ }^{10}$.

Some studies have found high prevalences of opportunistic parasites such as C. parvum in 4-8\% of the cases with diarrhoea in HIV+ patients and $13-45 \%$ in AIDS patients ${ }^{17}$, as well as C. cayetanensis, Isospora

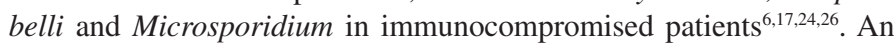
overall prevalence of opportunistic parasites of $9.0 \%$ of the patients was observed during the present study, the species most frequently encountered being $C$. parvum, Strongyloides stercoralis and Microsporidia sp. Patients who presented microsporidia had CD4+ T lymphocytes counts of less than 50 cells $/ \mathrm{mm}^{3}$

Our results could have been affected by the prophylactic treatment with albendazol that all patients except HIV+ individuals received as standard protocol in the different health care centres, before being remitted to the laboratory (data not shown). However a faecal contamination index of $39.0 \%$ was obtained, indicating that evaluations should be made more frequently to prevent these infections from becoming more serious health problems for immunocompromised patients due to greater susceptibility.

\section{RESUMO}

Frequência de parasitas intestinais em pacientes imunocomprometidos com e sem manifestações gastrointestinais: estudo preliminar

O objetivo do presente estudo é avaliar a frequência de parasitas intestinais em pacientes com alterações imunológicas. Foram analisadas 111 pessoas com leucemia linfóide aguda (LLA), leucemia mieloide crônica, virus da imunodeficiência humana (VIH) e outras doenças, principalmente alterações sanguíneas. Para cada indivíduo foram realizados exames seriados de fezes tanto com solução salina quanto com lugol \#3, direto e por concentração, culturas de fezes e colorações específicas.

Não houve diferenças significativas na frequência de parasitoses nos distintos grupos avaliados. A frequência de parasitas potencialmente patogênicos foi de $32.4 \%$ (36/111) enquanto a de parasitas oportunistas foi de $9.0 \%$ (10/111). As espécies mais observadas foram $C$. parvum, microsporídios spp. e $S$. stercoralis. 


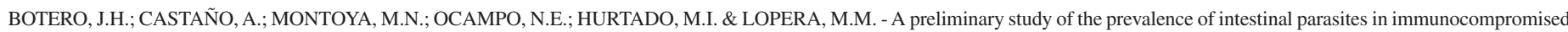
patients with and without gastrointestinal manifestations. Rev. Inst. Med. trop. S. Paulo, 45(4): 197-200, 2003.

\section{ACKNOWLEDGEMENTS}

We thank the Adult Haematology and Child Haematology Laboratory of the HUSVP, the Immunology Laboratory (Primary Immunodeficiencies Section) of the School of Medicine of the University of Antioquia for the remission of patients, as well as Doctor Carlos Julio Montoya for correcting an earlier draft of this paper and the Committee for development of Research (CODI), Universidad de Antioquia for financial support.

\section{REFERENCES}

1. AMENT, M.E. \& RUBIN, C.E. - Relation of giardiasis to abnormal intestinal structure and function in gastrointestinal immunodeficiency syndromes. Gastroenterology, 62: 216-226, 1972.

2. BARRIGA, O. - Una visión personal de las reacciones inmunes contra las infecciones parasitarias. Parasit. al Día, 19: 119-129, 1995.

3. BOTERO, D. \& RESTREPO, M. - Tecnicas de Laboratorio en parasitologia médica. In: BOTERO, D. \& RESTREPO, M. Parasitosis humanas. 3. ed. Medellín, CIB, 1998. p. $409-437$.

4. BUSH, A.; FERNÁNDEZ J.; ESCH, G. \& SEED, R. - Kinds of parasites and hosts. In: BUSH, A.; FERNÁNDEZ, J.; ESCH, G. \& SEED, R.C.U. Parasitism: the diversity and ecology of animal parasites. Cambridge, 2001. p. 12.

5. CASTAÑO, A. - Microsporidios, parasitos oportunistas. In: CARMONA, J. Topicos de infectología. Medellín, Litoimpresos, 1995. p. 69-79.

6. CONNOLLY, G.M.; DRYDEN, M.S.; SHANSON, D.C. \&. GAZZARD, B.G. Cryptosporidial diarrhoea in AIDS and its treatment. Gut, 29: 593-597, 1988.

7. CORREDOR, A.; ARCINIEGAS, E. \& HERNÁNDEZ, C. - Parasitismo intestinal. In: MINISTERIO DE SALUD. Investigación nacional de morbilidad. Santafe de Bogotá, 2000.

8. GALÁN, R.; AGUALIMPIA, C.; CORREDOR, A. \& VEGA, E. - El parasitismo intestinal. In: MINISTERIO DE SALUD. Investigación nacional de morbilidad. Bogotá, 1969.

9. GARCIA, D.; MONTOYA, C. \& SALGADO, H. et al. - Detección y manejo de infección recurrente patológica. Dirección Seccional de Salud de Antioquia. Boletín epidemiológico de Antioquia, Medellín, 1995.

10. GENTA, R.M.; SCHAD, G.A. \& HELLMAN, M.E. - Strongyloides stercoralis: parasitological, immunological and pathological observations in immunosuppressed dogs. Trans. roy. Soc. trop. Med. Hyg., 80: 34-41, 1986.

11. GENTILE, G.; VENDITTI, M.; MICOZZI, A. et al. - Cryptosporidiosis in patients with hematologic malignancies. Rev. infect. Dis., 13: 842-846, 1991.

12. IGRA-SIEGMAN, Y.; KAPILA, R.; SEN, P.; KAMINSKI, Z.C. \& LOURIA, D.B. Syndrome of hyperinfection with Strongyloides stercoralis. Rev. infect. Dis., 3: 397 407, 1981 .
13. JANOFF, E.N.; LIMAS, C.; GEBHARD, R.L. \& PENLEY, K.A. - Cryptosporidial carriage without symptoms in the acquired immunodeficiency syndrome (AIDS). Ann. Intern. Med., 112: 75-76, 1990.

14. JANOFF, E.N.; SMITH, P.D. \& BLASER, M.J. - Acute antibody responses to Giardia lamblia are depressed in patients with AIDS. J. infect. Dis., 157: 798-804, 1988.

15. LAUGHON, B.E.; DRUCKMAN, D.A.; VERNON, A. et al. - Prevalence of enteric pathogens in homosexual men with and without acquired immunodeficiency syndrome. Gastroenterology, 94: 984-993, 1988.

16. MANDELL, G.; BENNET, J. \& DOLIN, R. - Giardia lamblia. In: Principles and practices of infectious diseases. 4. ed. New York, Churchill Livingstone, 1995. p. 2487-2493.

17. MANNHEIMER, S.B. \& SOAVE, R. - Protozoal infections in patients with AIDS. Cryptosporidiosis, isosporiasis, cyclosporiasis, and microsporidiosis. Infect. Dis. Clin. North Amer., 8: 483-498, 1994.

18. MONTOYA, M. - Cyclospora: un nuevo patógeno In: CARMONA, J. Tópicos de infectología. Medellín, Litoimpresos, 1995. p. 61-67.

19. MOURA, H.; DA SILVA, J.L.; SODRE, F.C. et al. - Gram-chromotrope: a new technique that enhances detection of microsporidial spores in clinical samples. J. euk. Microbiol., 43: 94S-95S, 1996.

20. NEUTRA, M.R. \&. KRAEHENBUHL, J.P. - Mucosal immunization via M cells for production of protective secretory IgA antibodies. Amer. J. trop. Med. Hyg., 50(suppl.): 10-13, 1994.

21. PURTILO, D.T.; MEYERS, W.M. \& CONNOR, D.H. - Fatal strongyloidiasis in immunosuppressed patients. Amer. J. Med., 56: 488-493, 1974.

22. ROMAGNANI, S. - Biology of human TH1 and TH2 cells. J. clin. Immunol., 15: 121$129,1995$.

23. ROTTERDAM, H. \& TSANG, P. - Gastrointestinal disease in the immunocompromised patient. Hum. Path., 25: 1123-1140, 1994.

24. SMITH, P.D.; LANE, H.C.; GILL, V.J. et al. - Intestinal infections in patients with the acquired immunodeficiency syndrome (AIDS). Etiology and response to therapy. Ann. intern. Med., 108: 328-333, 1988.

25. SNELLER, M. \& CLIFFORD, H. - Infections in the immunocompromised host. In: RICH, R. Clinical immunology principles and practices. St Louis, Mosby, 1996. p. $579-593$.

26. SOUZA-DIAS, R.; MANGINI, A.C.; TORRES, D. et al. - Cryptosporidiosis among patients with acquired immunodeficiency syndrome (AIDS) in the county of São Paulo, Brazil. Rev. Inst. Med. trop. S. Paulo, 30: 310-312, 1988.

27. UNANUE, E.R. - The 1995 Albert Lasker Medical Research Award. The concept of antigen processing and presentation. J. Amer. med. Ass., 274: 1071-1073, 1995.

28. WEBER, R.; BRYAN, R.T.; SCHWARTZ, D.A. \& OWEN, R.L. - Human microsporidial infections. Clin. Microbiol. Rev., 7:. 426-461, 1994.

Received: 18 June 2001

Accepted: 21 July 2003 